\title{
The role of PKC in CXCL8 and CXCL10 directed prostate, breast and leukemic cancer cell migration
}

\author{
Enana Alassaf and Anja Mueller* \\ School of Pharmacy, University of East Anglia, Norwich NR4 7TJ, UK, Telephone: \\ 0044(0)1603-593138, Fax: 0044(0)1603-592003, email: anja.mueller@uea.ac.uk
}

${ }^{*}$ Correspondence to this author

\begin{abstract}
Migration of tumour cells is a fundamental process for the formation and progression of metastasis in malignant diseases. Chemokines binding to their cognate receptors induce the migration of cancer cells, however, the molecular signalling pathways involved in this process are not fully understood. Protein kinase $C(P K C)$ has been shown to regulate cell migration, adhesion and proliferation. In order to identify a connection between PKC and tumour progression in breast, prostate and leukaemia cells, the effect of PKC on CXCL8 or CXCL10-mediated cell migration and morphology was analysed. We tested the speed of the migrating cells, morphology, and chemotaxis incubated with different PKC isoforms

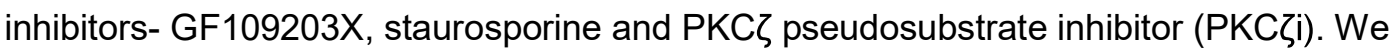
found that the migration of CXCL8-driven PC3 and MDA-MB231 cells in the presence of conventional, novel or atypical PKCs was not affected, but atypical PKC $\zeta$ is crucial for THP-1 chemotaxis. The speed of CXCL10-activated PC3 and MDA-MB231 cells was significantly reduced in the presence of conventional, novel and atypical PKC 3 . THP-1 chemotaxis was again affected by atypical PKCそi. On the other hand, cell area, circularity or aspect ratio were affected by staurosporine in CXCL8 or CXCL10-activated cells, demonstrating a role of $\mathrm{PKCa}$ in the rearrangement of the cytoskeleton regardless of the effect on the migration. Consequently, this allows the speculation that different PKC isoforms induce different outcomes in migration and actin cytoskeleton based on the chemokine receptor and/or the cell type.
\end{abstract}

\section{Keywords}

CXCR1, CXCR2, CXCR3, Migration, Protein Kinase C, Morphology, Chemokine Receptors 


\section{Introduction}

The process of secondary tumour formation is called metastasis and it is the leading cause for patient death (Seyfried and Huysentruyt., 2013). This process does not happen randomly, instead it is structured and biased to specific tissues (Chaffer and Weinberg, 2011; Pauli et al., 1990). It is well established that chemokines have a role in directing organ-specific metastasis (O'Hayre et al., 2008).

CXCL8 was first reported for its attraction of leukocytes to the site of inflammation (Paccaud et al., 1990; Yoshimura et al., 1987). CXCL8 binds to two receptors: CXCR1 and CXCR2. Other chemokines can bind to CXCR1 and CXCR2 but CXCL8 is the most intensively studied chemokine for its association with inflammation and cancer (Ha et al., 2017). CXCR1 and CXCR2 receptors are expressed on the surface of leukocytes (Campbell et al., 2013). CXCL8 released by cancer cells is known to promote tumour proliferation and metastasis (Campbell et al., 2013; Gales et al., 2013; Ha et al., 2017; Liu et al., 2016). Otherwise, CXCL8 is barely detected in normal tissues (Hoffmann et al., 2002). Upon receptor activation, $\mathrm{Ga}_{\mathrm{i}}$, is activated and regulates several signalling pathways which are important for neutrophil stimulation and chemotaxis (Wu et al., 2016). $\mathrm{Ga}_{i}$ mainly inhibit adenylate cyclase (AC) and transduces signals through tyrosine kinase such as Src (Thelen, 2001). The release of G $\beta y$ stimulates phospholipase $C$ (PLC) leading to the release of calcium and activation of protein kinase $C(P K C)$. This is thought to be crucial for neutrophil chemotaxis (Wu et al., 2016).

Likewise, elevated levels of CXCL10 have been reported in a diverse range of human diseases such as infectious, inflammatory, autoimmune disorders, and cancer (Liu et al., 2011a, 2011b; Tokunaga et al., 2018). CXCL10 has a vital role in the recruitment and homing of leukocytes to the inflamed area (Antonelli et al., 2014). CXCL10, together with CXCL9 and CXCL11, bind to CXCR3 which is expressed on T cells, and is involved in leukocyte migration (Liu et al., 2005). CXCR3 is present in normal plasma cells and multiple myeloma cells causing their chemotaxis to the bone marrow (Giuliani et al., 2006; Moser et al., 2006). Moreover, studies reported the expression of CXCR3 in significant amounts in cancer cells like melanoma (Kawada et al., 2004; Robledo et al., 2001) and malignant B lymphocytes (Trentin et al., 1999). Further studies showed that CXCR3 expression is associated with breast (Ma et al., 2009), osteosarcoma (Pradelli et al., 2009), and colon metastasis (Cambien et al., 2009; Kawada et al., 2007)

PKCs are a multifunctional proteins serine/threonine kinases, consisting of 15 isoforms classified into three categories based on their second messenger requirements: conventional PKCs (cPKCs- $\alpha, \beta I, \beta I I, y)$ requires DAG (diacylglycerol) and calcium; novel PKCs $(n P K C s-\delta, \varepsilon, \eta, \theta)$ requires DAG only and atypical PKCs (aPKCs- $\zeta, ~ I(\lambda)$ are not 
directly activated by the PLC $\beta$ (phospholipase c) signalling pathway. PKCs can affect the morphology of the cells thereby regulating processes such as cell migration (Larsson, 2006).

During cell migration, actin filaments arrange in three-dimensional assemblies preparing for the next move. The leading edge of the cell will contain protrusive structures called lamellipodia and filopodia. When activated, an elongation of the protrusion of the leading edge will lead the cell movement (Labrousse et al., 2003). On the other hand, the contraction of the cells is generated by stress fibres acting as contractile structures. They are formed of actin and myosin bundles, also known as actomyosin structures, generating contractile forces for cell migration and morphogenesis [(Lauffenburger and Horwitz, 1996). Here we analyse the effect of PKC on CXCL8 or CXCL10-mediated cell migration and morphology.

\section{Materials and methods}

\subsection{Cells and materials}

The breast cancer cell line MDA-MB231 cells and the metastatic prostate cancer PC3 cells were obtained from ATCC (Teddington, UK). These cells were maintained in growth media, DMEM and RPMI (respectively), containing 1\% non-essential amino acids, 10\% FCS (fetal calf serum) and $2 \mathrm{mM} \mathrm{L-glutamine.} \mathrm{Cells} \mathrm{were} \mathrm{grown} \mathrm{in} \mathrm{an} \mathrm{incubator} \mathrm{under} \mathrm{standard}$ conditions of $37{ }^{\circ} \mathrm{C}, 5 \% \mathrm{CO}_{2}$ and air $95 \%$. CXCL8 was a gift from K. Schmitz (TU Darmstadt)

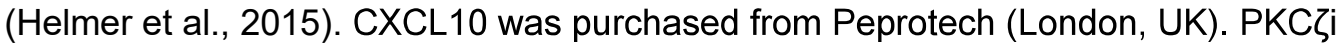
myristoylated was obtained from Calbiochem (Hertfordshire, UK) and from Tocris (Abingdon, UK). Staurosporine and GF109203X were purchased from Tocris (Abingdon, UK). The concentration of the inhibitors used are $10 \mu \mathrm{M}$ PKC $\zeta$ i, $10 \mathrm{nM}$ staurosporine and $5 \mu \mathrm{M}$ GF109203X.

\subsection{Time-lapse cell migration assay}

The effect of CXCL8 and CXCL10 on the migration speed of the cells was observed using time-lapse videos microscopy. MDA-MB231 and PC3 cells were seeded out in a 24-well plate in complete RPMI and DMEM, respectively, for $24 \mathrm{~h}$ at $37^{\circ} \mathrm{C}$. Equivalent concentrations of $10 \mu \mathrm{M}$ PKC $\zeta \mathrm{i}, 10 \mathrm{nM}$ staurosporine or $5 \mu \mathrm{M}$ GF109203X were added to the cells in addition to CXCL8 or CXCL10. Using Carl Zeiss AxioVision Rel. 4.8 software, timelapse images were taken every $4 \mathrm{~min}$ for $10 \mathrm{~h}$ at $10 \mathrm{X}$ objective in a controlled chamber of $37^{\circ} \mathrm{C}, 5 \% \mathrm{CO}_{2}$ and air $95 \%$. Time-lapse videos created were analysed using Fij//Image $\mathrm{J}$ software where 10 cells in each video were tracked manually throughout the video frames. The speed sum of each individual cell was averaged over the course of experiments. All the experiments were repeated at least four times. 


\subsection{Chemotaxis assay}

THP- 1 cells were collected and centrifuged at a concentration of $25 \times 10^{4} / \mathrm{ml}$ in serum free RMPI 1640 containing $0.1 \%$ BSA (bovine serum albumin). The lower chambers of the microchemotaxis well plate (Receptor Technologies, Adderbury, UK) were blocked with $1 \%$ BSA for $30 \mathrm{~min}$, followed by the addition of the vehicle or chemokines at $31 \mu \mathrm{l}$. CXCL8 was used at a concentration of $5 \mathrm{nM}$ and CXCL10 at $1 \mathrm{nM}$, and were diluted with $0.1 \%$ serum free RPMI. The cells, on the other hand, were incubated with the inhibitor treatment or vehicle for $30 \mathrm{~min}$ and loaded at $20 \mu \mathrm{l}$ volume to the top chamber of the polyvinylprollidonefree polycarbonate filter ( $5 \mu \mathrm{m}$ pores). The chemotaxis plate was accommodated in the incubator at $37{ }^{\circ} \mathrm{C}, 100 \%$ humidity, and $5 \% \mathrm{CO} 2$ for $4 \mathrm{~h}$ to allow cells to migrate. The filter was then removed and the migrating cells at the lower chamber were counted using a haemocytometer. All the experiments were repeated at least three times.

\subsection{Cell morphology analysis}

Besides measuring the cell migratory speed using time-lapse videos, cellular morphology was measured as well using Fij//mage $\mathrm{J}$. The last frame of the videos indicating $10 \mathrm{~h}$ of cells migration was screenshotted. Using the free hand drawing option, cells were drawn around and measurements of area, aspect ratio and circularity were made using the Analyse and Set measurement options. Subsequently, these parameters were averaged for 70 cells per image per experiment and the experiments were repeated at least three times.

\subsection{Actin staining}

PC3 and MDA-MB231 cells were harvested, seeded onto 12 well coverslips, and left to adhere overnight. Inhibitors were added with or without CXCL8 or CXCL10 (10 nM) to the wells and left to incubate for $10 \mathrm{~h}$ at $37^{\circ} \mathrm{C}$ and $5 \% \mathrm{CO}_{2}$. Cells were washed twice with PBS (phosphate buffered salt solution) and fixed with $4 \%$ paraformaldehyde for $15 \mathrm{~min}$. Cells were washed again with PBS and $0.1 \%$ Triton X-100 (FisherBioTech) solution was added for 5 min. Cells were washed again twice with PBS and incubated with 1:100 Phalloidin-iFlour 488 Conjugate (Abcam) in PBS for 30 min. Coverslips were mounted onto glass slides with DPX mounting media (Fisher Scientific). Stained cells were then imaged at $63 \mathrm{X}$ objective using Leica DMIL inverted microscope.

\subsection{Immunofluorescence staining}

MDA-MB231 and PC3 cells were seeded out on a glass cover-slides in complete media in a 12-well plate for $24 \mathrm{~h}$ at $37^{\circ} \mathrm{C}, 5 \% \mathrm{CO}_{2}$ and air $95 \%$. Cells were then washed twice in cold PBS and fixed with $4 \%$ paraformaldehyde for $15 \mathrm{~min}$ while being incubated at $4{ }^{\circ} \mathrm{C}$. After 
washing twice with PBS, cells were blocked with IL-8RA (CXCR1) antibody (SC-7303, Santa Cruz Biotechnology, USA); IL-8RB (CXCR2) antibody (SC-7304, Santa Cruz Biotechnology, USA) and CXCR-3 (H-1) antibody (SC-133087 Santa Cruz Biotechnology, USA) were used at 1:500 dilution and incubated for $1 \mathrm{~h}$ at $4^{\circ} \mathrm{C}$. After washing with cold PBS, cells were incubated with the corresponding secondary antibodies Alexa Fluor 488-conjugated goat anti-mouse IgG (Abcam, Cambridge, MA). Cells were further washed with PBS and incubated with DAPI (4',6 diamidino-2-phenylindole) (MERCK). THP-1 cells were harvested and centrifuged and the same process was applied to them except they were stained in their tubes instead of in a well plate. Finally, slides were mounted with DPX (Fisher). The stained cells were analyzed for CXCR1, 2 and 3 surface expression using a Leica DMII inverted microscope.

\subsection{Cell viability studies}

MTS assay was performed using a CellTiter 96® AQueous Non-Radioactive Cell Proliferation Assay (Promega). $100 \mu \mathrm{l}$ cells were seeded at $1 \times 10^{5} \mathrm{ml}^{-1}$ in complete RPMl for PC3 cells and DMEM for MDA-MB231 cells overnight. PKC inhibitors were added to the cells and incubated for $24 \mathrm{~h}$ at $37^{\circ} \mathrm{C}, 5 \% \mathrm{CO}_{2}$ and air $95 \%$. To validate the toxicity of the inhibitors on the cells, MTS compound was added for $2 \mathrm{~h}$ and conducted as described previously (Mills et al., 2016).

\subsection{Statistical data analysis}

Data analysis was performed using GraphPad Prism V6 software (La Jolla, CA). Unpaired ttest was used to analyse two-variables while One-way ANOVA with post-hoc Dunnett's multiple comparison was performed on three or more variables. Shapiro-Wilk test was used to confirm normal distribution of data. Friedman non-parametric test with post Dunn's multiple comparison tests were applied for normalized values. Data represents the mean \pm S.D. at least three independent experiment repeats.

\section{Results}

\subsection{CXCL8 and CXCL10-induced chemotaxis in THP-1 cells is inhibited by PKC}

The effect of PKC inhibitors was studied on chemokine-induced cell chemotaxis for different receptors using THP-1 cells. These cells express CXCR2 and CXCR3 but not CXCR1 as confirmed using immunofluorescence assay (Fig 1A). The expression of CXCR2 but not CXCR1 was already confirmed in a study by (Phillips et al., 2005). Here, 5 MM GF109203X (inhibits $\mathrm{CPKC}$ ( $\alpha$ and $\beta 1$ ) and $\mathrm{nPKC}(\delta$ and $\varepsilon$ ), $10 \mathrm{nM}$ staurosporine (inhibits $\mathrm{CPKC}$ ( $\alpha$ and $\gamma$ ) and $\mathrm{nPKC}(\eta)$, as well as $10 \mu \mathrm{M}$ PKC $\zeta$ i were incubated with the cells. Initially, there was a significant difference in the migration of the untreated basal sample and the CXCL8- 
activated sample ( $p \leq 0.05)$, and with CXCL10 activation (P $\leq 0.05)$. Although GF109203X and staurosporine did not cause an inhibitory effect on the cells, PKC $\zeta i$ resulted in a significant reduction of chemotaxis towards CXCL8 and CXCL10 (Fig 1B, C). An MTS assay determined there was no cellular toxicity regarding these inhibitors over the timeframe and concentrations used (Fig 1D).

\subsection{PKC isoform activation is not important for CXCL8-induced migration in PC3 and MDA-MB231 cells}

To study the importance of PKC signalling pathway on the migration speed of PC3 and MDA-MB231 cells activated by CXCL8, a time-lapse migration assay was conducted. Both cell lines express CXCR1 and CXCR2 receptors (Fig 2A). Cells were incubated with different PKC inhibitors; $5 \mu \mathrm{M}$ GF109203X, $10 \mathrm{nM}$ staurosporine, or $10 \mu \mathrm{M}$ PKC $\zeta \mathrm{i}$, and activated with 10 nM CXCL8.

The basal speed of MDA-MB231 cells was $21.07 \pm 7.1 \mu \mathrm{m} / \mathrm{h}$, whereas the addition of CXCL8 increased the speed by almost two-fold to $42.6 \pm 7.7 \mu \mathrm{m} / \mathrm{hr}(\mathrm{P}=0.006)$ (Table 1).

There were no crucial changes to cell speeds with the treatment of staurosporine $(44.0 \pm 5.3$ $\mu \mathrm{m} / \mathrm{h})$, GF109203X (36.9 $\pm 4.8 \mu \mathrm{m} / \mathrm{h})$, or PKC $3 \mathrm{i}(34.5 \pm 7.6 \mu \mathrm{m} / \mathrm{h})($ Fig $2 \mathrm{~B})$.

Furthermore, the basal speed of PC3 cells was $23.7 \pm 5.4 \mu \mathrm{m} / \mathrm{h}$, while CXCL8 addition increased the speed to $58.2 \pm 16.8 \mu \mathrm{m} / \mathrm{h}(\mathrm{P}=0.001)$ (Table 1). The treatment with staurosporine or GF109203X caused the average migratory speed to slightly drop, although not significantly, to $42.4 \pm 12.1 \mu \mathrm{m} / \mathrm{h}$, and $43.4 \pm 14.4 \mu \mathrm{m} / \mathrm{h}$, respectively. Finally, the treatment with PKC $\zeta$ i caused a moderate drop where an average speed of $35.4 \pm 10.4 \mu \mathrm{m} / \mathrm{h}$ was calculated $(P=0.077)$ (Fig 2C).

\subsection{CXCL10 relies on PKC signalling for migration of PC3 and MDA-MB231 cells}

PC3 and MDA-MB231 cells both express CXCR3 receptor (Fig 2A), which is confirmed by other reports (Goldberg-Bittman et al., 2004; Wu et al., 2012), respectively. Two of the PKC

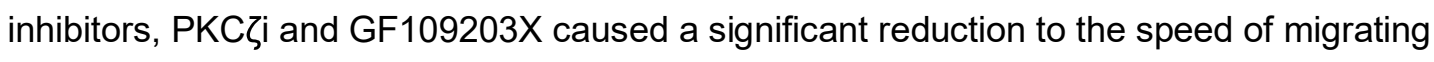
MDA-MB231 cells when activated with CXCL10 (10 nM). Indeed, the basal speed of cells was $18.9 \pm 6.3 \mu \mathrm{m} / \mathrm{h}$, and CXCL10 addition gave a speed of $31.2 \pm 5.2 \mu \mathrm{m} / \mathrm{h}(P=0.015)$, whereas the treatment with PKC $\zeta$ i caused a significant decrease to the speed of migration to $20.1 \pm 3.2 \mu \mathrm{m} / \mathrm{h}(P=0.019)$ and a further reduction to $17.6 \pm 2.6 \mu \mathrm{m} / \mathrm{h}(P=0.002)$ with GF109203X. Staurosporine, however, did not cause a crucial difference to the migratory speed; $29.8 \pm 5.6 \mu \mathrm{m} / \mathrm{h}(P=0.944)$ (Fig 3A). Moreover, PC3 cells migrate at an average speed of $18.9 \pm 2.7 \mu \mathrm{m} / \mathrm{h}$, whilst the activation with CXCL10 boosted the speed by almost three-fold to $50.4 \pm 3.4 \mu \mathrm{m} / \mathrm{h}(\mathrm{P}=0.017)$ (Fig 3B). A speed of $16.6 \pm 3.4 \mu \mathrm{m} / \mathrm{h}$ was calculated 
with the treatment of PKC $\mathrm{i}(P=0.006)$, GF 109203X had a speed of $26.9 \pm 9 \mu \mathrm{m} / \mathrm{h}(P=0.002)$, and with staurosporine the speed was $32.3 \pm 5.8 \mu \mathrm{m} / \mathrm{h}(\mathrm{P}=0.001)$ (Table 2$)$. MTS assay showed no cytotoxicity of PKC inhibitors towards both cell lines (Fig 3C, D).

\subsection{PKC inhibitor staurosporine influences the cellular morphology of PC3 and MDA- MB231 cells}

Staurosporine drastically changed the shape of MDA-MB231 cells to a more stretched and elongated shape in the presence of CXCL8 $(10 \mathrm{nM})$ or CXCL10 (10 nM). This was reflected on the area, cell circularity and aspect ratio which were significantly different (Fig 4A, B). Moreover, PC3 cellular morphology analyses have also been changed in the presence of staurosporine and CXCL8 or CXCL10, in particular, the area, aspect ratio and circularity were affected (Fig 5A, B). These results were confirmed using an actin stain for MDA-MB231 and PC3 cells. Actin-enriched lamellipodia and membrane ruffles demonstrated by the red arrows (Fig 6) pointed at the tips of CXCL8 or CXCL10-activated PC3 cells treated with staurosporine. The same treatment with MDA-MB231 cells yielded to a similar outcome with the formation of sticky protrusions on cells' both ends making them form a web of actindistributed stretched cells (Fig S1). GF109203X had only a mild effect on the aspect ratio of CXCL10-activated PC3 cells. PKCZi did not cause a major change to the cell morphology in both PC3 and MDA-MB231 cells with or without CXCL8 or CXCL10.

\section{Discussion}

Overexpression of chemokine receptors is thought to be a contributing factor in providing navigational cues for cancer cells to metastasize (Singh et al., 2011). Therefore, investigating the mechanisms of migration can give a better understanding on how to block the motility of cancer cells. CXCL8 acting on its cognate receptors, CXCR1 and CXCR2, within the tumour microenvironment was found to be associated with cancer migration and proliferation (Ha et al., 2017). Also, CXCR3 is found to be expressed in lymphatic leukaemia, splenic marginal zone lymphoma and breast cancer cells (Goldberg-Bittman et al., 2004), suggesting its correlation to tumour progression and metastasis (Suyama et al., 2005). Although many studies have been trying to address the main signalling pathways involved in cell migration, there is still a knowledge gap with regards to whether PKC signalling is a positive or negative factor in cancer metastasis. Our approach was to investigate the role PKC plays in the migration and morphology change of different cancer cells which have been activated by either CXCL8 or CXCL10.

We studied the role of PKC family members in chemokine mediated migration using small molecule inhibitors acting on different subtypes (Fig 7). We have already reported that PKC inhibition does not inhibit CCL3 migration in THP-1 cells (Cardaba et al., 2012). However, we 
also found that PKC and PKD were important for the migration of CXCL12-activated PC3 cells (Hamshaw et al., 2019). In addition, the migration of CXCL12-stimulated MCF-7 cells was reported to be blocked by PKC inhibitors but not Jurkat cells (Mills et al., 2016). In this report we observe that both CXCL8 or CXCL10 promote cells to migrate faster comparing with the untreated control, yet when we added PKC inhibitors, cells reacted differently based on the chemokine and PKC inhibitor used.

Conventional (PKC $\alpha, \beta, \gamma)$, novel (PKC $\eta, \delta, \varepsilon)$, or atypical PKC isozymes are not important for CXCL8-induced MDA-MB231 and PC3 cells migration, but atypical PKC $\zeta$ is crucial for THP-1 cells migration. The PKC inhibitor GF109203X- a less specific inhibitor of PKCa, $\beta 1$, $\delta$, and $\varepsilon$, staurosporine- inhibitor of PKCa, $y$ and $\eta$, as well as PKC $\zeta i$ did not affect the speed of migration of PC3 and MDA-MB231 cells when activated with CXCL8. However, using these same set of inhibitors on THP-1 cells chemotaxis, we found that only PKC $\mathrm{i}$ significantly reduced the number of cells migrating toward CXCL8. Simultaneously, it was

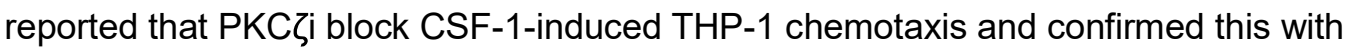
knocking down PKC $\zeta$ with siRNA technique (Guo et al., 2009). Likewise, PKC $\zeta$ inhibition has reduced the chemotactic abilities of EGF-induced non-small cell lung cancer cells (Liu et al., 2009). On the other hand, GF109203X had lowered renal cancer cell migration using chemotaxis assay (Brenner et al., 2008) and blocked CCL5-mediated migration (Chuang et al., 2009). Additionally, in former studies we reported that knocking down PKCa in MCF-7 and Jurkat cells has abrogated cells migration towards CXCL12, while PKC $\zeta$ did not have an effect (Mills et al., 2016). Taking it all together, we conclude that atypical PKC $\zeta$ i block the migration of CXCL8-activated THP-1 cells, while PKCZi, GF109203X and staurosporine did not have an effect on the CXCL8-induced migration of PC3 and MDA-MB231 cells. In contrast, using the same set of inhibitors, we found that staurosporine, GF109203X and PKCZi reduced the migration of CXCL10-activated PC3 cells, but staurosporine did not have an effect on the migration speed of MDA-MB231 cells, and PKCZi was crucial for THP-1 cells chemotaxis. Subsequently, we speculate that different PKC isoforms generate different effects on migration based on the chemokine receptor and/or the cell type.

Cell migration is characterized by a series of morphological changes endorsed by dynamic modification of actin polymerization causing rearrangement of the cytoskeleton (Lamalice et al., 2007). Accumulating evidence have confirmed that PKC substrates phosphorylate many cytoskeletal proteins triggering dynamic alternations that lead cell adhesion and migration (Keenan and Kelleher, 1998; Larsson, 2006; Quann et al., 2011). Treating cells with PKC inhibitors have presented some contradicting results in relation to the migration and cytoskeleton rearrangement based on the chemokine used. Although GF109203X, PKC and staurosporine did not cause a substantial difference to the migration speed of CXCL8activated PC3 and MDA-MB231 cells, staurosporine induced a significant change to the 
area, circularity or aspect ratio of both cell lines by the morphology analysis of images taken using brightfield microscopy (data not shown). This was confirmed with observations of phalloidin-stained actin microfilaments with fluorescence microscopy generating major actin disruption to the cells with staurosporine treatment with both chemokines and both cell lines. Actin-enriched lamellipodia and membrane ruffles appeared at the tips of CXCL8-activated PC3 cells treated with staurosporine (Fig 6). The same treatment with MDA-MB231 cells showed a tangled network of cells overlapping over each other as well as stretching their cytoskeleton (Fig S1). Staurosporine-treated cells displayed long spindled shapes with thinning to their cell bodies exhibiting sticky endings with slender protrusions. Cell migration involving polymerization and depolymerisation of actin filaments in lamellipodia or membrane ruffles (Lauffenburger and Horwitz, 1996) were not affected by the changes staurosporine cause on both cell lines suggesting a different independent mechanism of action taking place.

CXCL10-activated cells were not affected by PKC $\zeta$ i, but staurosporine and GF109203X caused some morphological changes to the PC3 and MDA-MB231 cells. GF109203X significantly changed the aspect ratio of CXCL10-activated PC3 cells. Our group previously reported that GF109203X reduce the size of CXCL12-activated PC3 cells with an increase to the number of cellular protrusions (Hamshaw et al., 2019). Another study found that overexpression of PKCE (one of the PKC isoforms inhibited by GF109203X) displayed a polarized shape change to fibroblasts resulting in the formation of long cellular membrane protrusions [35]. PKC $\varepsilon$ was found to associated with Rac1 activation (Wang, 2006), which is known for its role in migration and formation of lamellipodia (Mills et al., 2017), (Ridley, 2001). Indeed, PKCE expression was already confirmed in prostate cancer cells (Wang, 2006). Another possibility for the morphology change assumed by GF109203X treatment is that RhoA could act downstream of PKC which leads to actin reorganisation. This was evident by a study that found that GF109203X block RhoA signalling in the vascular smooth muscle A7r5 cells (Brandt et al., 2002). In addition, it was proposed that PKCE could induce EMT via downstream signals RhoC and STAT3, which mediate EMT regulation (Aziz et al., 2010; Jain and Basu, 2014; Pan et al., 2005). Moreover, the circularity of CXCL10-activated MDA-MB231 cells and aspect ratio of PC3 cells were challenged by staurosporine resembled by a rapid and dramatic disruption of actin stress fibres with peripheral microspikes or filopodia formation in MDA-MB231 cells. Ruffles accumulating at the membrane of staurosporine CXCL10-treated PC3 cells were also observed. Collectively, although the morphological changes GF109203X and staurosporine induce on CXCL10activated PC3 cells were associated with a reduction of the migration speed of the cells, this was not the case with CXCL8-activated PC3 or MDA-MB231 cells. 
Staurosporine is a competitive PKC inhibitor with a high binding affinity and low specificity. It targets PKCa which has emerged as a general stimulator of cell spreading and migration by regulating actin-associated protein (Holinstat et al., 2003). The level of PKCa is elevated in PC3 (Rumsby et al., 2011) and breast cancer cells (O'Brian et al., 1989), therefore, blocking it with staurosporine might be the reason for the morphological changes observed earlier, although its effects cannot be explained merely by PKCa inhibition. Several studies have used staurosporine to induce cell apoptosis demonstrated by the change of cell morphology it causes and induction of JNK pathway. For example, it was found that treating astrocyte cells with staurosporine causes morphological changes to the actin and tubulin and related astrocytes death dependent on NOX family members (Olguín-Albuerne et al., 2014). Indeed, staurosporine is thought to promote apoptosis because of its inhibitory effect on the cell cycle (Abe et al., 1991) and it is related to the shape change of the cells. Staurosporine was also found to supress the proliferation of vascular endothelial cells but did not affect the migration of the cells (Oikawa et al., 1992). However, in our study, we used staurosporine at a nanomolar concentration (10 $\mathrm{nM}$ ) which did not cause cell toxicity using MTS assay (Fig 1 , 3). A study reported that using staurosporine at a nanomolar concentration induces rapid change of actin cytoskeleton in different cell types in PKC-deficient cells and argued that staurosporine might not be PKC dependent (Hedberg et al., 1990). Yet, our data show that staurosporine did not promote a change in the cells morphology unless they were stimulated with the chemokine, suggesting the role of PKC as a downstream signalling pathway involved in the specified cellular response. Taken together, the chemokine, cell type and dose of staurosporine defines its effect on cell mortality, mobility and/or morphology, this is mostly due to its non-selectivity.

In summary, the PKC family is a large one that could exhibit extensive range of effects on the cells (Larsson, 2006) with each PKC isoenzyme phosphorylating a spectrum of intracellular signalling proteins in distinct subcellular locations (Cornford et al., 1999). We conclude that PKC $\zeta$ is important for the migration of CXCL8 or CXCL10-activated THP-1 cells and CXCL10-activated PC3 cells, whereas it is not important for CXCL8-stimulated PC3 or MDA-MB231 cells. CXCL10-stimulated PC3 cells were more sensitive to PKC inhibitors than MDA-MB231 cells, while stimulation with CXCL8 did not cause a difference to the migration speed for both cell lines. Moreover, the intriguing effect of staurosporine was demonstrated by its ability to drastically change the morphology of the cells, regardless of its impact on the cell migration, suggesting different mechanisms or signalling molecules involved in the process. Although these results reveal some of the roles of PKCs, but they also add to the complexity of this system, therefore, requires further investigation on a larger number of cell types and more specific inhibitors. 


\section{Acknowledgment}

We thank the studentship offered by UEA's Sanctuary scholarship, and Monica Malik for her generous donation to support the PhD scholarship for E.A.

\section{References}

Abe, K., Yoshida, M., Usui, T., Horinouchi, S., Beppu, T., 1991. Highly synchronous culture of fibroblasts from $\mathrm{G} 2$ block caused by staurosporine, a potent inhibitor of protein kinases. Exp. Cell Res. 192, 122-127. https://doi.org/10.1016/0014-4827(91)90166-R

Antonelli, A., Ferrari, S.M., Giuggioli, D., Ferrannini, E., Ferri, C., Fallahi, P., 2014.

Chemokine (C-X-C motif) ligand (CXCL)10 in autoimmune diseases. Autoimmun. Rev. 13, 272-280. https://doi.org/10.1016/j.autrev.2013.10.010

Aziz, M.H., Hafeez, B.B., Sand, J.M., Pierce, D.B., Aziz, S.W., Dreckschmidt, N.E., Verma, A.K., 2010. Protein kinase C mediates Stat3Ser727 phosphorylation, Stat3-regulated gene expression, and cell invasion in various human cancer cell lines through integration with MAPK cascade (RAF-1, MEK1/2, and ERK1/2). Oncogene 29, 3100 3109. https://doi.org/10.1038/onc.2010.63

Brandt, D., Gimona, M., Hillmann, M., Haller, H., Mischak, H., 2002. Protein kinase C induces actin reorganization via a Src- and Rho-dependent pathway. J. Biol. Chem. 277, 20903-20910. https://doi.org/10.1074/jbc.M200946200

Brenner, W., Greber, I., Gudejko-Thiel, J., Beitz, S., Schneider, E., Walenta, S., Peters, K., Unger, R., Thüroff, J.W., 2008. Migration of renal carcinoma cells is dependent on protein kinase $C \delta$ via $\beta 1$ integrin and focal adhesion kinase. Int. J. Oncol. 32, 11251131. https://doi.org/10.3892/ijo.32.5.1125

Cambien, B., Karimdjee, B.F., Richard-Fiardo, P., Bziouech, H., Barthel, R., Millet, M.A., Martini, V., Birnbaum, D., Scoazec, J.Y., Abello, J., Saati, T. Al, Johnson, M.G., Sullivan, T.J., Medina, J.C., Collins, T.L., Schmid-Alliana, A., Schmid-Antomarchi, H., 2009. Organ-specific inhibition of metastatic colon carcinoma by CXCR3 antagonism. Br. J. Cancer 100, 1755-1764. https://doi.org/10.1038/sj.bjc.6605078

Campbell, L.M., Maxwell, P.J., Waugh, D.J.J., 2013. Rationale and Means to Target ProInflammatory Interleukin-8 (CXCL8) Signaling in Cancer. Pharmaceuticals 929-959. https://doi.org/10.3390/ph6080929

Cardaba, M.C., Jacques, R.O., Barrett, J.E., Hassell, K.M., Kavanagh, A., Remington, F.C., Tse, T., Mueller, A., 2012. CCL3 induced migration occurs independently of intracellular calcium release. Biochem. Biophys. Res. Commun. 418, 17-21.

https://doi.org/10.1016/j.bbrc.2011.12.081 
Chaffer, C.L., Weinberg, R.A., 2011. A perspective on cancer cell metastasis. Science (80). 331, 1559-1564. https://doi.org/10.1126/science.1203543

Chuang, J.-Y., Yang, W.-H., Chen, H.-T., Huang, C.-Y., Tan, T.-W., Lin, Y.-T., Hsu, C.-J., Fong, Y.-C., Tang, C.-H., 2009. CCL5/CCR5 axis promotes the motility of human oral cancer cells. J. Cell. Physiol. 220, 418-426. https://doi.org/10.1002/jcp.21783

Cornford, P., Evans, J., Dodson, A., Parsons, K., Woolfenden, A., Neoptolemos, J., Foster, C.S., 1999. Protein kinase $C$ isoenzyme patterns characteristically modulated in early prostate cancer. Am. J. Pathol. 154, 137-144. https://doi.org/10.1016/S00029440(10)65260-1

Edlund, M., Sung, S.Y., Chung, L.W.K., 2004. Modulation of prostate cancer growth in bone microenvironments. J. Cell. Biochem. 91, 686-705. https://doi.org/10.1002/jcb.10702

Gales, D., Clark, C., Manne, U., Samuel, T., 2013. The Chemokine CXCL8 in Carcinogenesis and Drug Response. ISRN Oncol. 2013, 859154. https://doi.org/10.1155/2013/859154

Giuliani, N., Bonomini, S., Romagnani, P., Lazzaretti, M., Morandi, F., Colla, S., SaraTagliaferri, Lasagni, L., FrancescoAnnunziato, Crugnola, M., Rizzoli, V., Pangalis, G.A., General, L., 2006. CXCR3 and its binding chemokines in myeloma cells: expression of isoforms and potential relationships with myeloma cell proliferation and survival. Haematologica 11, 1489-1497.

Goldberg-Bittman, L., Neumark, E., Sagi-Assif, O., Azenshtein, E., Meshel, T., Witz, I.P., Ben-Baruch, A., 2004. The expression of the chemokine receptor CXCR3 and its ligand, CXCL10, in human breast adenocarcinoma cell lines. Immunol. Lett. 92, 171178. https://doi.org/10.1016/j.imlet.2003.10.020

Guo, H., Ma, Y., Zhang, B., Sun, B., Niu, R., Ying, G., Zhang, N., 2009. Pivotal Advance: $\mathrm{PKC} \zeta$ is required for migration of macrophages. J. Leukoc. Biol. 85, 911-918. https://doi.org/10.1189/jlb.0708429

Ha, H., Debnath, B., Neamati, N., 2017. Role of the CXCL8-CXCR1 / 2 Axis in Cancer and Inflammatory Diseases. Theranostics 7. https://doi.org/10.7150/thno.15625

Hamshaw, I., Ajdarirad, M., Mueller, A., 2019. The role of PKC and PKD in CXCL12 directed prostate cancer migration. Biochem. Biophys. Res. Commun. 519, 86-92. https://doi.org/10.1016/j.bbrc.2019.08.134

Hedberg, K.K., Birrell, G.B., Habliston, D.L., Griffith, O.H., 1990. Staurosporine induces dissolution of microfilament bundles by a protein kinase $\mathrm{C}$-independent pathway. Exp. Cell Res. 188, 199-208. https://doi.org/10.1016/0014-4827(90)90160-C Helmer, D., Rink, I., Dalton, J.A.R., Brahm, K., Jöst, M., Nargang, T.M., Blum, W., Wadhwani, P., Brenner-Weiss, G., Rapp, B.E., Giraldo, J., Schmitz, K., 2015. Rational design of a peptide capture agent for CXCL8 based on a model of the CXCL8:CXCR1 
complex. RSC Adv. 5, 25657-25668. https://doi.org/10.1039/C4RA13749C

Hoffmann, E., Dittrich-Breiholz, O., Holtmann, H., Kracht, M., 2002. Multiple control of interleukin-8 gene expression. J. Leukoc. Biol. 72, 847-55.

Holinstat, M., Mehta, D., Kozasa, T., Minshall, R.D., Malik, A.B., 2003. Protein kinase Cainduced p115RhoGEF phosphorylation signals endothelial cytoskeletal rearrangement. J. Biol. Chem. 278, 28793-28798. https://doi.org/10.1074/jbc.M303900200

Jain, K., Basu, A., 2014. Protein kinase C- $\varepsilon$ promotes EMT in breast cancer. Breast Cancer Basic Clin. Res. 8, 61-67. https://doi.org/10.4137/BCBCR.S13640

Kawada, K., Hosogi, H., Sonoshita, M., Sakashita, H., Manabe, T., Shimahara, Y., Sakai, Y., Takabayashi, A., Oshima, M., Taketo, M.M., 2007. Chemokine receptor CXCR3 promotes colon cancer metastasis to lymph nodes. Oncogene 26, 4679-4688. https://doi.org/10.1038/sj.onc.1210267

Kawada, K., Sonoshita, M., Sakashita, H., Takabayashi, A., Yamaoka, Y., Manabe, T., Inaba, K., Minato, N., Oshima, M., Taketo, M.M., 2004. Pivotal role of CXCR3 in melanoma cell metastasis to lymph nodes. Cancer Res. 64, 4010-4017. https://doi.org/10.1158/0008-5472.CAN-03-1757

Keenan, C., Kelleher, D., 1998. Protein kinase C and the cytoskeleton. Cell. Signal. 10, 225232. https://doi.org/10.1016/S0898-6568(97)00121-6

Labrousse, A.M., Zappaterra, M.D., Rube, D.A., Bliek, V. Der, Cell, M., Sesaki, H., Jensen, R.E., Biol, J.C., Arimura, S., Tsutsumi, N., Natl, P., Sci, A., Ent, F. Van Den, Amos, L., Lowe, J., Micro-, C.O., Ridley, A.J., Schwartz, M.A., Burridge, K., Firtel, R.A., Ginsberg, M.H., Borisy, G., Parsons, J.T., Horwitz, A.R., 2003. Cell Migration : Integrating Signals from Front to Back 302, 1704-1710.

Lamalice, L., Le Boeuf, F., Huot, J., 2007. Endothelial cell migration during angiogenesis. Circ. Res. 100, 782-794. https://doi.org/10.1161/01.RES.0000259593.07661.1e

Larsson, C., 2006. Protein kinase $\mathrm{C}$ and the regulation of the actin cytoskeleton. Cell. Signal. 18, 276-284. https://doi.org/10.1016/j.cellsig.2005.07.010

Lauffenburger, D.A., Horwitz, A.F., 1996. Cell migration: A physically integrated molecular process. Cell 84, 359-369. https://doi.org/10.1016/S0092-8674(00)81280-5

Liu, L., Callahan, M.K., Huang, D.R., Ransohoff, R.M., 2005. Chemokine Receptor CXCR3: An Unexpected Enigma. Curr. Top. Dev. Biol. 68, 149-181. https://doi.org/10.1016/S0070-2153(05)68006-4

Liu, M., Guo, S., Hibbert, J.M., Jain, V., Singh, N., Wilson, N.O., Stiles, J.K., 2011a. CXCL10/IP-10 in infectious diseases pathogenesis and potential therapeutic implications. Cytokine Growth Factor Rev. 22, 121-130. https://doi.org/10.1016/j.cytogfr.2011.06.001

Liu, M., Guo, S., Stiles, J.K., 2011b. The emerging role of CXCL10 in cancer (Review). 
Oncol. Lett. 2, 583-589. https://doi.org/10.3892/ol.2011.300

Liu, Q., Li, A., Tian, Y., Wu, J.D., Liu, Y., Li, T., Chen, Y., Han, X., Wu, K., 2016. The CXCL8-CXCR1/2 pathways in cancer. Cytokine Growth Factor Rev. 31, 61-71. https://doi.org/10.1016/j.cytogfr.2016.08.002

Liu, Y., Wang, B., Wang, J., Wan, W., Sun, R., Zhao, Y., Zhang, N., 2009. Down-regulation of $\mathrm{PKC} \zeta$ expression inhibits chemotaxis signal transduction in human lung cancer cells. Lung Cancer 63, 210-218. https://doi.org/10.1016/j.lungcan.2008.05.010

Ma, X., Norsworthy, K., Kundu, N., Rodgers, W.H., Gimotty, P.A., Goloubeva, O., Lipsky, M., Li, Y., Holt, D., Fulton, A., 2009. CXCR3 expression is associated with poor survival in breast cancer and promotes metastasis in a murine model. Mol. Cancer Ther. 8, 490498. https://doi.org/10.1158/1535-7163.MCT-08-0485

Mills, S.C., Goh, P.H., Kudatsih, J., Ncube, S., Gurung, R., Maxwell, W., Mueller, A., 2016. Cell migration towards CXCL12 in leukemic cells compared to breast cancer cells. Cell. Signal. 28, 316-324. https://doi.org/10.1016/j.cellsig.2016.01.006

Mills, S.C., Howell, L., Beekman, A., Stokes, L., Mueller, A., 2017. Rac1 plays a role in CXCL12 but not CCL3-induced chemotaxis and Rac1 GEF inhibitor NSC23766 has off target effects on CXCR4. Cell. Signal. 42, 88-96.

https://doi.org/10.1016/j.cellsig.2017.10.006

Moser, K., Muehlinghaus, G., Manz, R., Mei, H., Voigt, C., Yoshida, T., Dörner, T., Hiepe, F., Radbruch, A., 2006. Long-lived plasma cells in immunity and immunopathology. Immunol. Lett. 103, 83-85. https://doi.org/10.1016/j.imlet.2005.09.009

O'Brian, C.A., Ward, N.E., Vogel, V.G., Singletary, S.E., 1989. Elevated Protein Kinase C Expression in Human Breast Tumor Biopsies Relative to Normal Breast Tissue. Cancer Res. 49, 3215-3217.

O'Hayre, M., Salanga, C.L., Handel, T.M., Allen, S.J., 2008. Chemokines and cancer: migration, intracellular signalling and intercellular communication in the microenvironment. Biochem. J. 409, 635-649. https://doi.org/10.1042/BJ20071493

Oikawa, T., Shimamura, M., Ashino, H., Nakamura, O., Kanayasu, T., Morita, I., Murota, S.I., 1992. Inhibition of angiogenesis by staurosporine, a potent protein kinase inhibitor. J. Antibiot. (Tokyo). 45, 1155-1160. https://doi.org/10.7164/antibiotics.45.1155

Olguín-Albuerne, M., Domínguez, G., Morán, J., 2014. Effect of staurosporine in the morphology and viability of cerebellar astrocytes: Role of reactive oxygen species and NADPH oxidase. Oxid. Med. Cell. Longev. 2014. https://doi.org/10.1155/2014/678371

Paccaud, J. p., Schifferli, J., Baggiolini, M., 1990. NAP-1/IL-8 Induced Up-regulation of CR1 receptors in human neutrophil leukocytes. Biochem. Biophys. Res. Commun. 166, 187192.

Pan, Q., Bao, L.W., Kleer, C.G., Sabel, M.S., Griffith, K.A., Teknos, T.N., Merajver, S.D., 
2005. Protein kinase $C \varepsilon$ is a predictive biomarker of aggressive breast cancer and a validated target for RNA interference anticancer therapy. Cancer Res. 65, 8366-8371. https://doi.org/10.1158/0008-5472.CAN-05-0553

Pauli, B.U., Augustin-Voss, H.G., El-Sabban, M.E., Johnson, R.C., Hammer, D.A., 1990. Organ-preference of metastasis - The role of endothelial cell adhesion molecules. Cancer Metastasis Rev. 9, 175-189. https://doi.org/10.1007/BF00046359

Phillips, R.J., Lutz, M., Premack, B., 2005. Differential signaling mechanisms regulate expression of CC chemokine receptor-2 during monocyte maturation. J. Inflamm. 2, 114. https://doi.org/10.1186/1476-9255-2-14

Pradelli, E., Karimdjee-Soilihi, B., Michiels, J.F., Ricci, J.E., Millet, M.A., Vandenbos, F., Sullivan, T.J., Collins, T.L., Johnson, M.G., Medina, J.C., Kleinerman, E.S., SchmidAlliana, A., Schmid-Antomarchi, H., 2009. Antagonism of chemokine receptor CXCR3 inhibits osteosarcoma metastasis to lungs. Int. J. Cancer 125, 2586-2594. https://doi.org/10.1002/ijc.24665

Quann, E.J., Liu, X., Altan-Bonnet, G., Huse, M., 2011. A Cascade of Protein Kinase C Isozymes Promotes Cytoskeletal Polarization in T Cells. Nat. Immunol. 176, 139-148. https://doi.org/10.1016/j.physbeh.2017.03.040

Ridley, A.J., 2001. Rho GTPases and cell migration. J Cell Sci 114, 2713-2722. https://doi.org/10.1083/jcb.150.4.807

Robledo, M.M., Bartolomé, R.A., Longo, N., Rodriguez-Frade, J.M., Mellado, M., Longo, I., Van Muijen, G.N.P., Sánchez-Mateos, P., Teixidó, J., 2001. Expression of Functional Chemokine Receptors CXCR3 and CXCR4 on Human Melanoma Cells. J. Biol. Chem. 276, 45098-45105. https://doi.org/10.1074/jbc.M106912200

Rumsby, M., Schmitt, J., Sharrard, M., Rodrigues, G., Stower, M., Maitland, N., 2011. Human prostate cell lines from normal and tumourigenic epithelia differ in the pattern and control of choline lipid headgroups released into the medium on stimulation of protein kinase C. Br. J. Cancer 104, 673-684. https://doi.org/10.1038/sj.bjc.6606077

Seyfried, T.N., Huysentruyt., L.C., 2013. On the origin of cancer metastsis. Crit. Rev. Oncog. 18, 43-73. https://doi.org/10.1002/1097-0142(195205)5:3<581::AIDCNCR2820050319>3.0.CO;2-Q

Singh, R., Lilladr, J.W., Singh, S., 2011. Chemokines: Key players in cancer progression and metastasis. Front. Biosci. - Sch. 3 S, 1569-1582. https://doi.org/10.2741/s246

Suyama, T., Furuya, M., Nishiyama, M., Kasuya, Y., Kimura, S., Ichikawa, T., Ueda, T., Nikaido, T., Ito, H., Ishikura, H., 2005. Up-regulation of the interferon Y (IFN-Y)-inducible chemokines IFN-inducible T-cell a chemoattractant and monokine induced by IFN- $\gamma$ and of their receptor CXC receptor 3 in human renal cell carcinoma. Cancer 103, 258267. https://doi.org/10.1002/cncr.20747 
Thelen, M., 2001. Dancing to the tune of chemokines. Nat. Immunol. 2.

Tokunaga, R., Zhang, W., Naseem, M., Puccini, A., Berger, M.D., Soni, S., McSkane, M., Baba, H., Lenz, H.J., 2018. CXCL9, CXCL10, CXCL11/CXCR3 axis for immune activation - A target for novel cancer therapy. Cancer Treat. Rev. 63, 40-47. https://doi.org/10.1016/j.ctrv.2017.11.007

Trentin, L., Agostini, C., Facco, M., Piazza, F., Perin, A., Siviero, M., Gurrieri, C., Galvan, S., Adami, F., Zambello, R., Semenzato, G., 1999. The chemokine receptor CXCR3 is expressed on malignant B cells and mediates chemotaxis. J. Clin. Invest. 104, 115121. https://doi.org/10.1172/JCl7335

Wang, Q.J., 2006. PKD at the crossroads of DAG and PKC signaling. Trends Pharmacol. Sci. 27, 317-323.

Wu, D., Larosa, G.J., Simon, M., 2016. G Protein-Coupled Signal Transduction Pathways for Interleukin-8. Science (80-. ). 261, 101-103.

Wu, Q., Dhir, R., Wells, A., 2012. Altered CXCR3 isoform expression regulates prostate cancer cell migration and invasion. Mol. Cancer 11, 1-16. https://doi.org/10.1186/14764598-11-3

Yoshimura, T., Matsushima, K., Tanaka, S., Robinson, E.A., Appella, E., Oppenheim, J.J., Leonard, E.J., 1987. Purification of a human monocyte-derived neutrophil chemotactic factor that has peptide sequence similarity to other host defense cytokines. Proc. Natl. Acad. Sci. U. S. A. 84, 9233-9237. https://doi.org/10.1073/pnas.84.24.9233

\section{Figure legends}

Figure 1. a) Immunofluorescence staining of the THP-1 cell line. Cells were treated with anti-CXCR1, anti-CXCR2 and anti-CXCR3 antibodies (green colour) and their corresponding secondary Alexa-488 conjugated antibodies. The nucleus is stained with DAPI (blue colour).

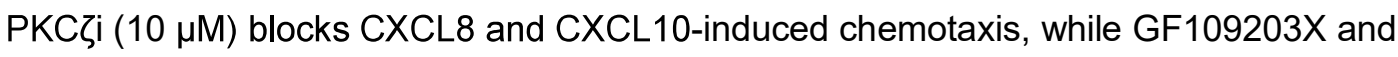
staurosporine do not. b) THP-1 chemotax towards $5 \mathrm{nM}$ CXCL8 in untreated basal cells or PKC inhibitors with CXCL8. c) THP-1 chemotax towards $1 \mathrm{nM} \mathrm{CXCL10} \mathrm{in} \mathrm{untreated} \mathrm{basal}$ cells or PKC inhibitors with CXCL10. Data shown are the mean \pm S.D. of at least 3 independent experiments. $\left({ }^{*}=\mathrm{P} \leq 0.05,{ }^{* *}=\mathrm{P} \leq 0.01\right.$, n.s. $=$ no significance $\mathrm{P}>0.05$, Oneway ANOVA with a Dunnett multiple comparisons test as post-test). d) MTS Assay shows no cytotoxicity of PKC inhibitors when incubated with THP-1 cells for $24 \mathrm{~h}$. Data representative of the mean \pm S.D. of three independent experiments. (n.s. $=$ no significance $P>0.05$, Kruskal-Wallis non-parametric test, Dunnett multiple comparison tests).

Figure 2. a) Immunofluorescence staining of the MDA-MB231 and PC3 cell lines. Cells were treated with anti-CXCR1, anti-CXCR2 and anti-CXCR3 antibodies (green colour) and their 
corresponding secondary Alexa-488 conjugated antibodies. The nucleus is stained with DAPI (blue colour). PKC inhibitors: GF109203X, staurosporine and PKCZi are not important for CXCL8-induced MDA-MB231 and PC3 cells migration using time-lapse cell motility assays. b) MDA-MB231 cells pre-treated with PKC inhibitors for $10 \mathrm{~h}$ in the presence of CXCL8 $(10 \mathrm{nM}), \mathrm{c})$ PC3 cells pre-treated with PKC inhibitors for $10 \mathrm{~h}$ in the presence of CXCL8 (10 nM). Data representative of the mean \pm S.D. of at least five independent experiments. (n.s.= no significance $\mathrm{P}>0.05$, One-way ANOVA with a Dunn's multiple comparisons test as post-test).

Figure 3. $P K C$ inhibitors are important for CXCL10-activated PC3 and MDA-MB231 cells. a) GF109203X and PKCZi slowed down the speed of MDA-MB231 cells significantly but staurosporine did not, b) staurosporine, GF109203X and PKCZi are also important for the migration of PC3 cells activated by CXCL10 as their speed were significantly reduced. Data representative of the mean \pm S.D. of five independent experiments. $\left({ }^{*}=P \leq 0.05,{ }^{* *}=P \leq\right.$ 0.01 , n.s. $=$ no significance $P>0.05$, One-way ANOVA with a Dunnett multiple comparisons test as post-test). MTS Assay shows no cytotoxicity of the PKC inhibitors when incubated with c) MDA-MB231 and d) PC3 cells for $24 \mathrm{~h}$. Data representative of the mean \pm S.D. of four independent experiments. (n.s.= no significance $P>0.05$, Kruskal-Wallis nonparametric test, Dunn's multiple comparison tests).

Figure 4. a) Staurosporine effects MDA-MB231 cellular morphology in the presence of CXCL10 (10 nM). i) basal MDA-MB231 cells, ii) MDA-MB231 with CXCL10, iii) pre-treated cells with staurosporine (10 $\mathrm{nM})$ and CXCL10, iv) pre-treated cells with GF109203X $(5 \mu \mathrm{M})$ and CXCL10, and v) pre-treated cells with PKC $\zeta(10 \mu \mathrm{M})$ and CXCL10. b) Cells were drawn around and measurements of area, aspect ratio and circularity were made of and averaged for 70 cells per image per experiment and the experiments were repeated at least three times. ${ }^{* * *}=\mathrm{P} \leq 0.001,{ }^{* * * *}=\mathrm{P} \leq 0.0001$, n.s. $=$ no significance $\mathrm{P}>0.05$, One-way ANOVA with a Dunnett multiple comparisons test as post-test).

Figure 5. a) Staurosporine effects PC3 cellular morphology in the presence of CXCL10. i) basal PC3 cells, ii) PC3 cells with CXCL10, iii) pre-treated cells with staurosporine (10 nM) and CXCL10, iv) pre-treated cells with GF109203X (5 $\mu \mathrm{M})$ and CXCL10, v) pre-treated cells with PKC $\zeta(10 \mu \mathrm{M})$ and CXCL10. b) Cells were drawn around and measurements of area, aspect ratio and circularity were made of and averaged for 70 cells per image per experiment and the experiments were repeated at least three times. Data representative of the mean \pm S.D. of five independent experiments. $\left({ }^{*}=P \leq 0.05,{ }^{* *}=P \leq 0.01\right.$, One-way ANOVA with a Dunnett multiple comparisons test as post-test). 
Figure 6. Staurosporine affects the cytoskeleton of CXCL8 and CXCL10 treated PC3 cells. Cells stained with phalloidin-iFluor 488 (green colour) and the nucleus stained with DAPI (blue colour). PC3 cells were activated with $10 \mathrm{nM}$ chemokine and treated with the different PKC inhibitors. Treatment with $10 \mathrm{nM}$ staurosporine resulted in the cells assuming a longspindled shape with thinning to their bodies exhibiting sticky endings with the red arrows demonstrating membrane ruffling and accumulation of lamellipodia.

Figure 7. Illustration of the effect of PKC inhibitors on CXCL8 or CXCL10-activated MDAMB231 or PC3 cells. 'No' denotes no effect, and 'Yes' denotes a significant effect on the cell migration speed or cellular morphology. 
는

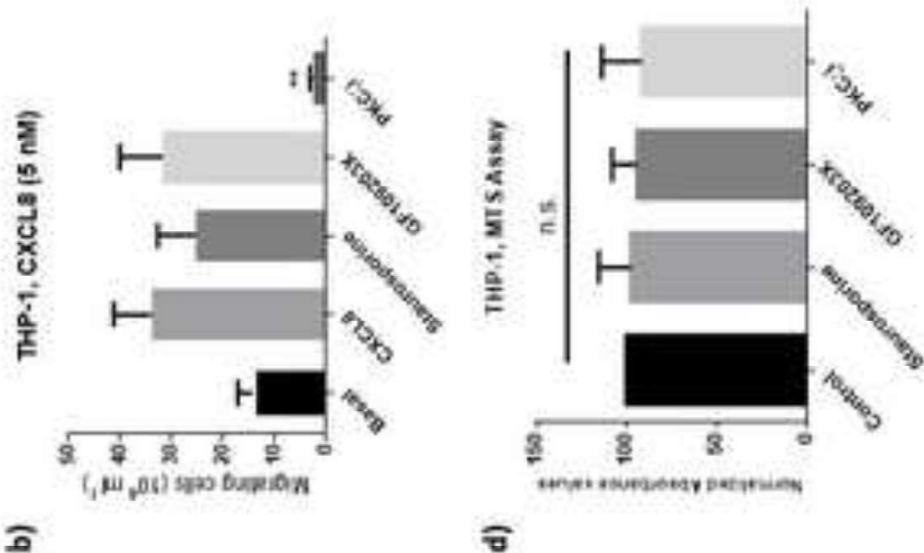

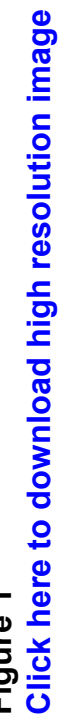

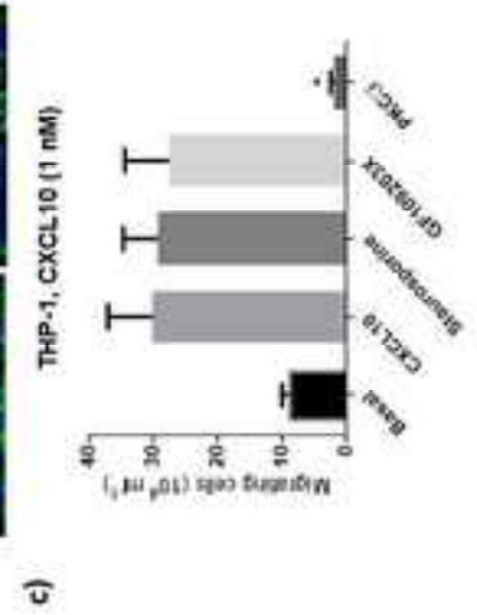


带
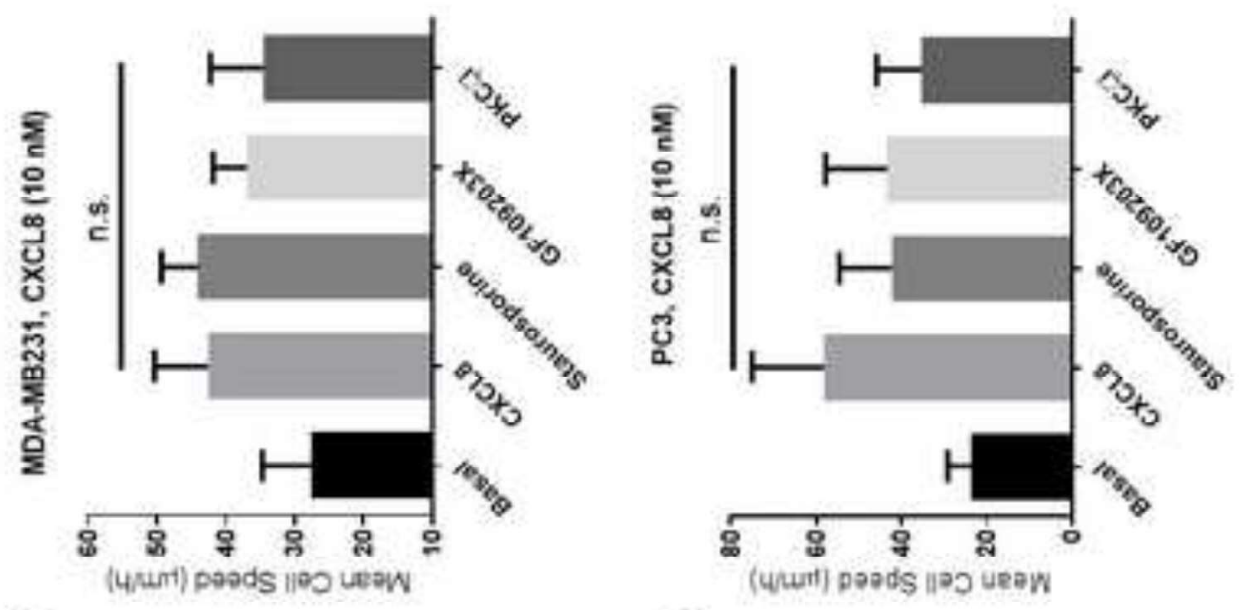

อ

ธ

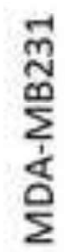

艺
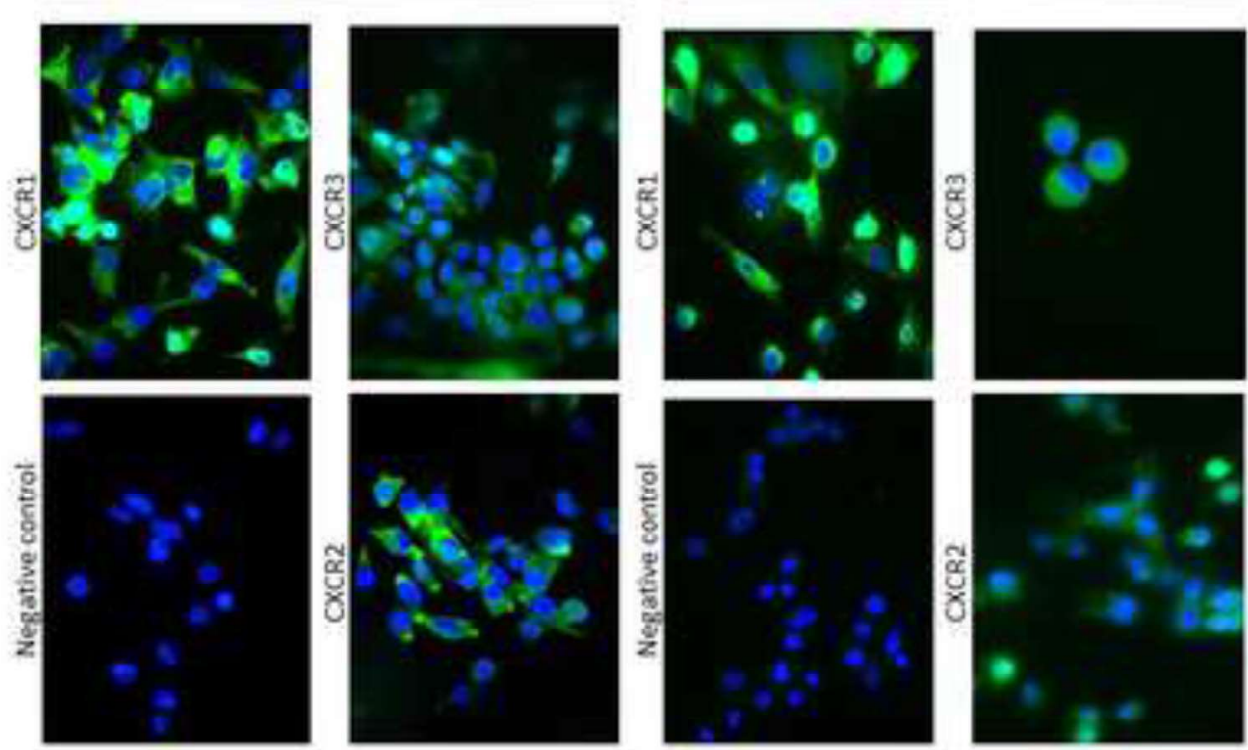

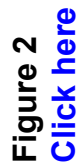




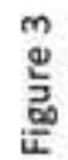
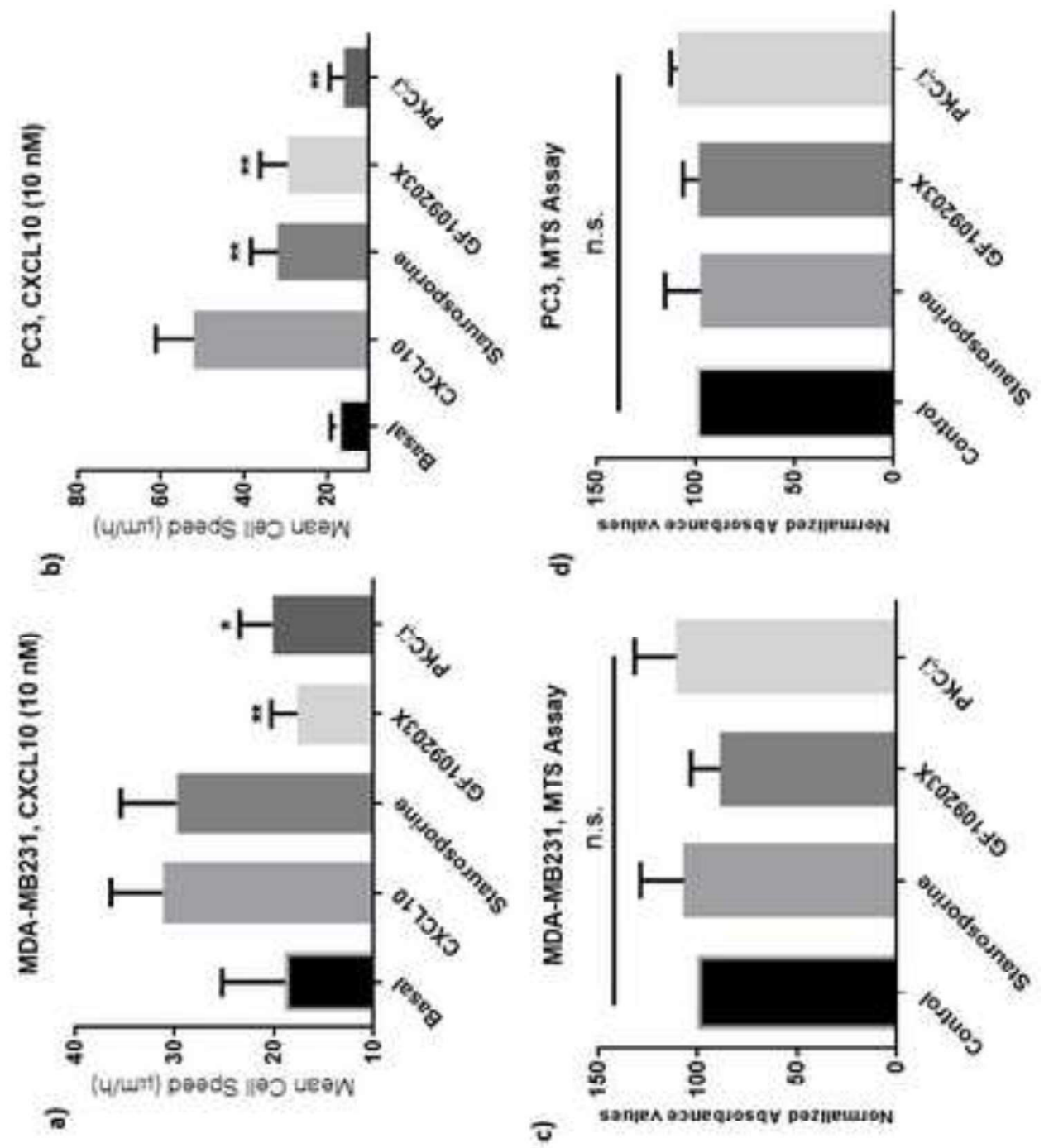


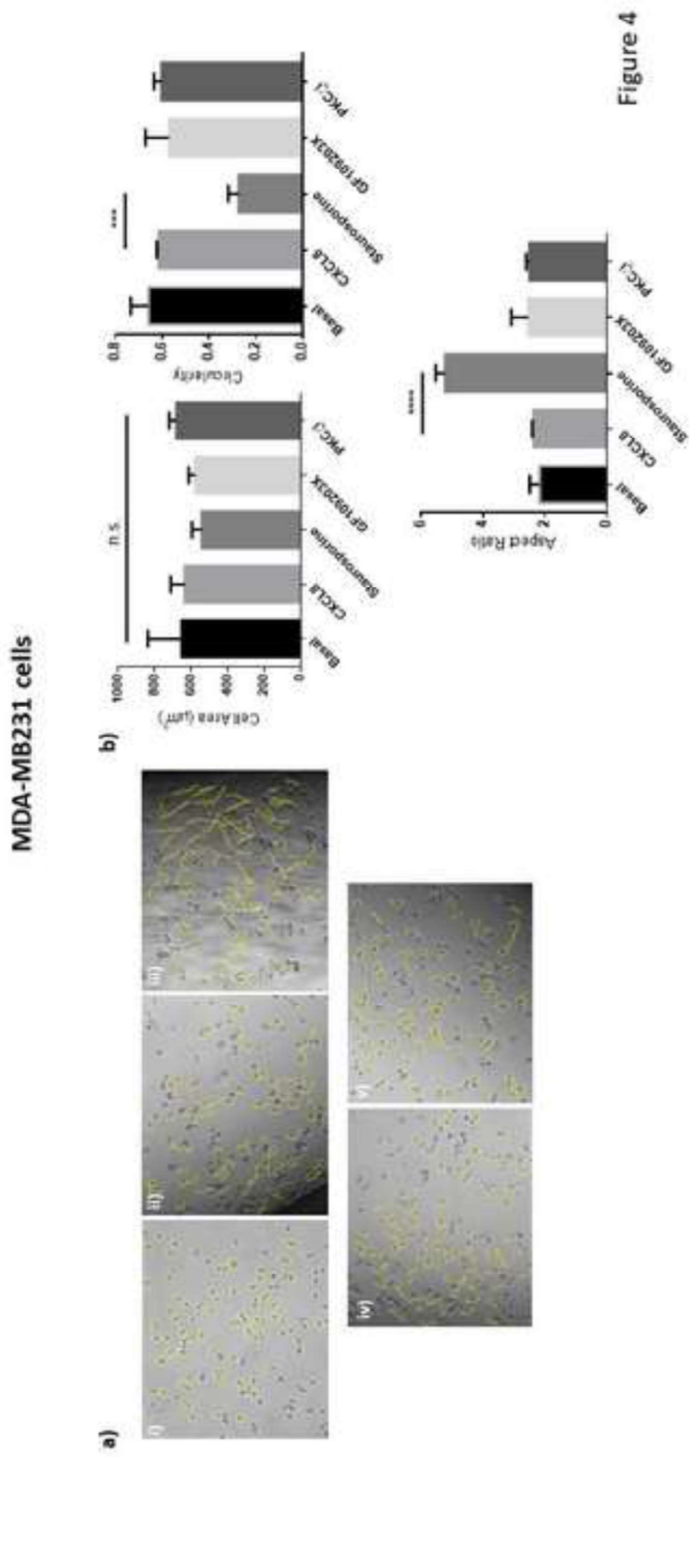




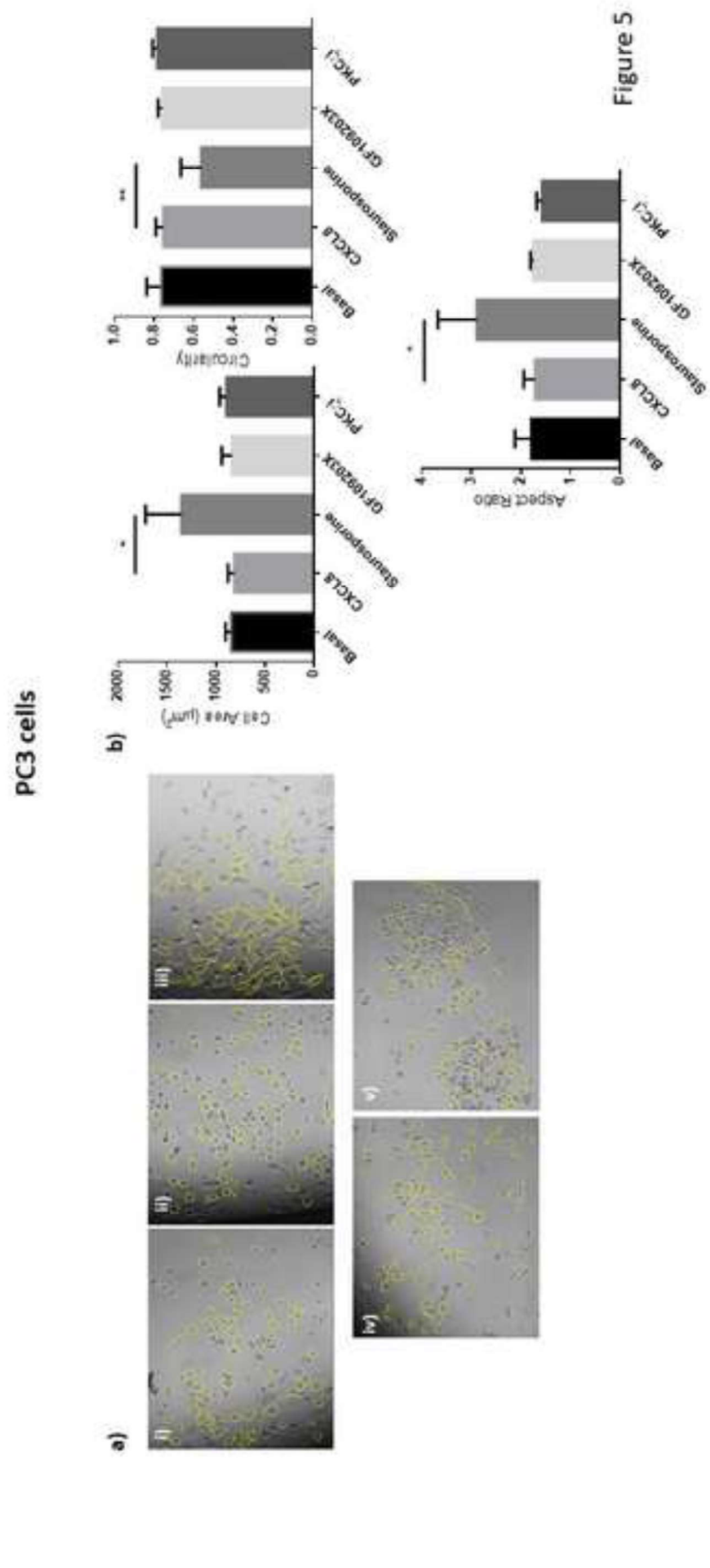


6
늘
$\frac{0}{2}$

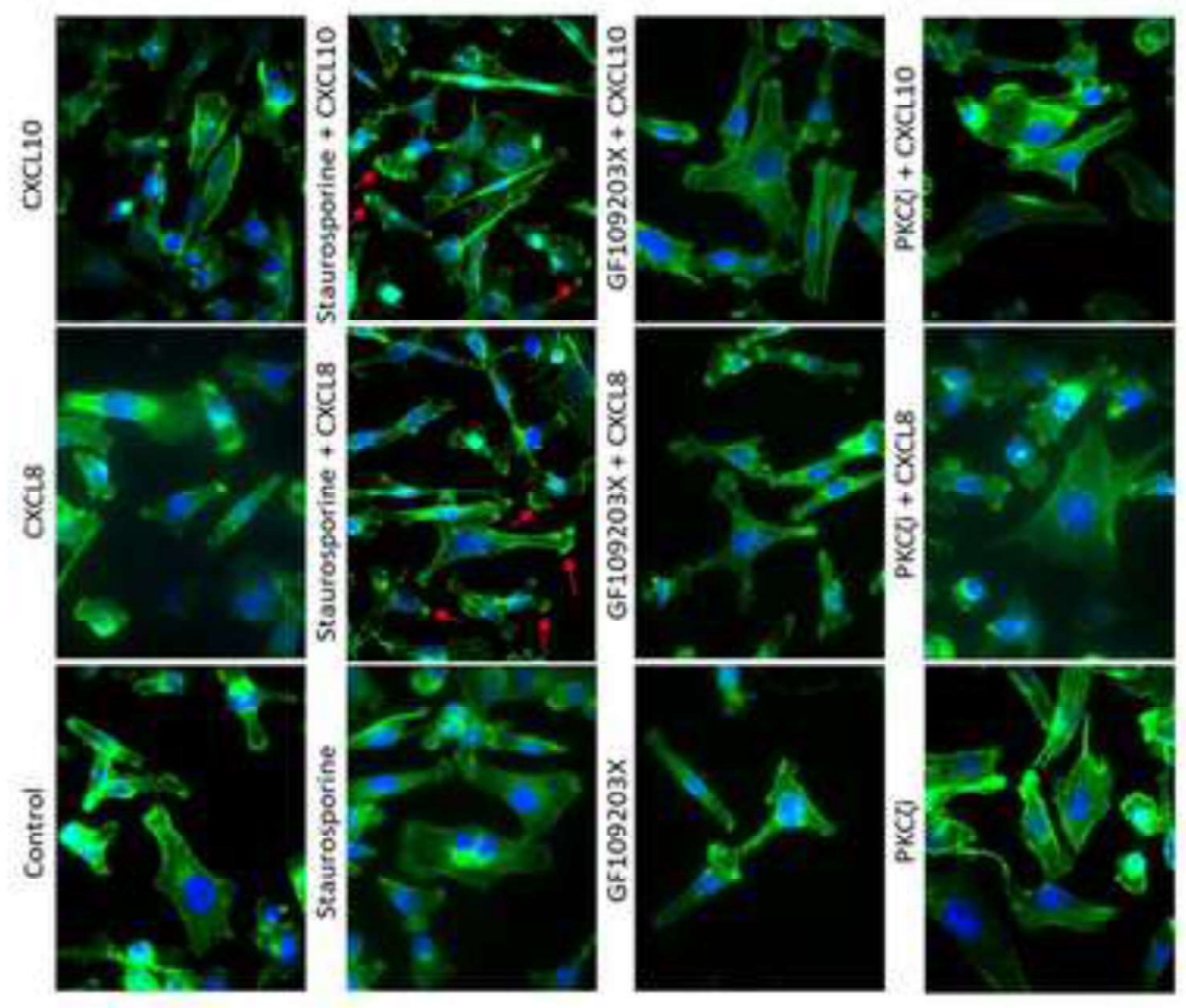

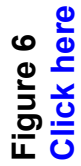


旁

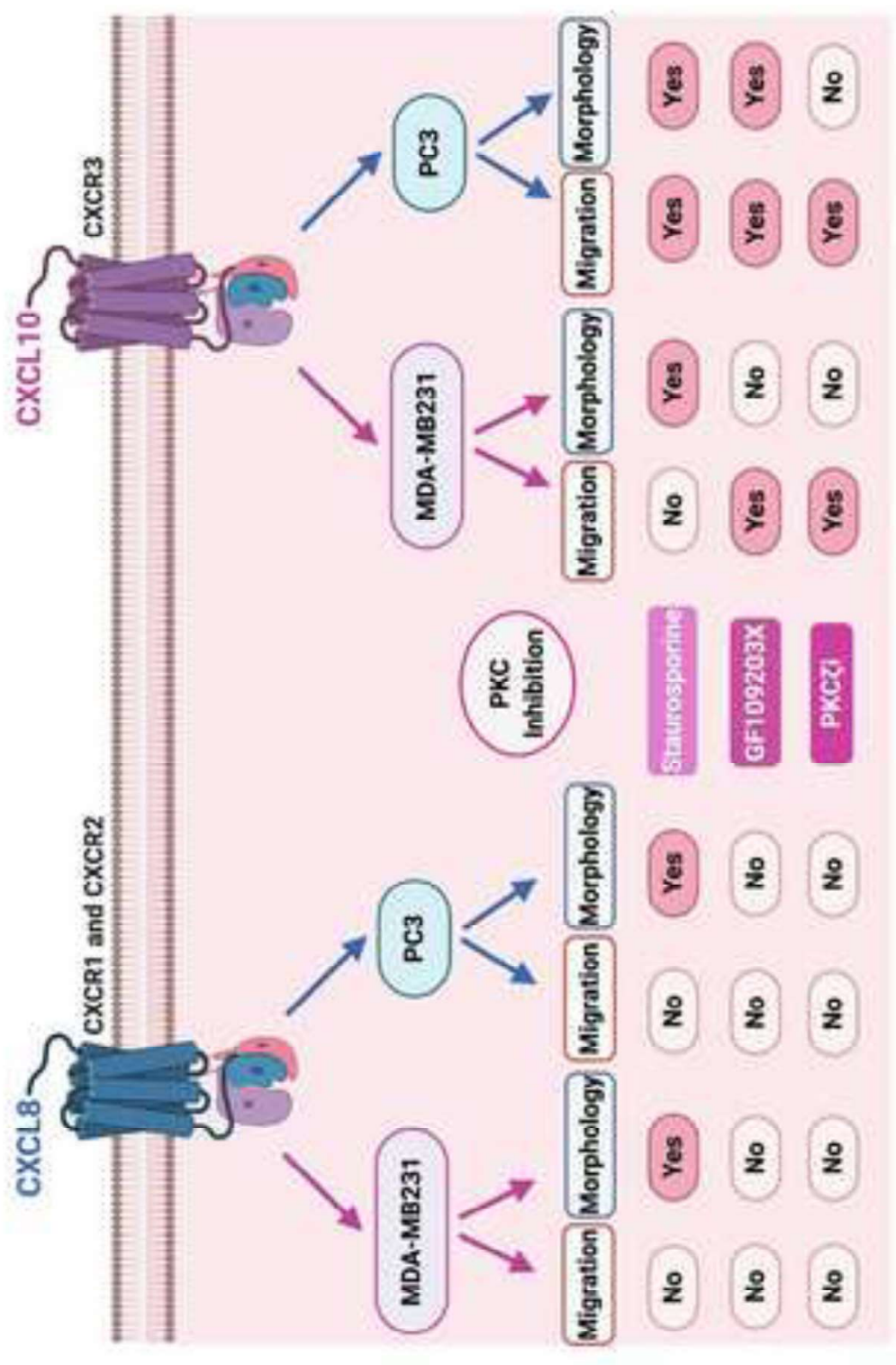

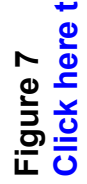


Table 1. The migration speed of PC3 and MDA-MB231 cells when activated with CXCL8 with or without PKC inhibitors. Data representative of the mean \pm S.D. of four independent experiments.

\begin{tabular}{|c|c|c|c|c|c|}
\hline & $\begin{array}{l}\text { Basal } \\
(\mu \mathrm{m} / \mathrm{h})\end{array}$ & $\begin{array}{l}10 \mathrm{nM} \\
\mathrm{CXCL8} \\
(\mu \mathrm{m} / \mathrm{h})\end{array}$ & $\begin{array}{l}10 \mathrm{nM} \\
\text { Staurosporine } \\
+10 \mathrm{nM} \\
\text { CXCL8 }(\mu \mathrm{m} / \mathrm{h})\end{array}$ & $\begin{array}{l}5 \mu \mathrm{M} \\
\text { GF109203X+ } \\
10 \mathrm{nM} \text { CXCL8 } \\
(\mu \mathrm{m} / \mathrm{h})\end{array}$ & $\begin{array}{l}10 \mu \mathrm{M} \text { PKC } \mathrm{i} \\
+10 \mathrm{nM} \\
\text { CXCL8 } \\
(\mu \mathrm{m} / \mathrm{h})\end{array}$ \\
\hline MDA-MB231 & $27.5 \pm 7.1$ & $42.6 \pm 7.7$ & $44.0 \pm 5.3$ & $36.9 \pm 4.8$ & $34.5 \pm 7.6$ \\
\hline PC3 & $23.7 \pm 5.4$ & $\begin{array}{l}58.2 \pm \\
16.8\end{array}$ & $42.4 \pm 12.1$ & $43.4 \pm 14.4$ & $35.4 \pm 10.4$ \\
\hline
\end{tabular}


Table 1. The migration speed of PC3 and MDA-MB231 when activated with CXCL10 with and without PKC inhibitors. Data representative of the mean \pm S.D. of four independent experiments.

\begin{tabular}{l|l|l|l|l|l} 
& $\begin{array}{l}\text { Basal } \\
(\mu \mathrm{m} / \mathrm{h})\end{array}$ & $\begin{array}{l}10 \mathrm{nM} \\
\mathrm{CXCL10} \\
(\mu \mathrm{m} / \mathrm{h})\end{array}$ & $\begin{array}{l}10 \mathrm{nM} \\
\text { Staurosporine } \\
+10 \mathrm{nM} \\
\mathrm{CXCL10}(\mu \mathrm{m} / \mathrm{h})\end{array}$ & $\begin{array}{l}\mathbf{5} \mathrm{\mu M} \\
\text { GF109203X } \\
10 \mathrm{nM} \text { CXCL10 } \\
(\mu \mathrm{m} / \mathrm{h})\end{array}$ & $\begin{array}{l}10 \mu \mathrm{MKC \zeta \textrm {i } + 1 0} \\
\mathrm{nM} \mathrm{CXCL10} \\
(\mu \mathrm{m} / \mathrm{h})\end{array}$ \\
\hline $\begin{array}{l}\text { MDA- } \\
\text { MB231 }\end{array}$ & $18.9 \pm 6.3$ & $\begin{array}{l}31.2 \pm \\
5.2\end{array}$ & $29.8 \pm 5.6$ & $17.6 \pm 2.6$ & $20.1 \pm 3.2$ \\
\hline PC3 & $18.9 \pm 2.7$ & $\begin{array}{l}50.4 \pm \\
8.7\end{array}$ & $32.3 \pm 5.8$ & $26.9 \pm 8.0$ & $16.6 \pm 3.4$
\end{tabular}


Supplementary material for online publication only
Click here to download Supplementary material for Click here to download Supplementary material for online publication only: Figure S1.jpg

.

\section{pg} $x^{2}$ $x^{2}$ .

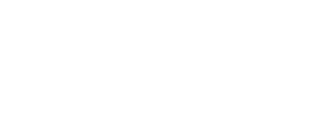
. (1) . . . .

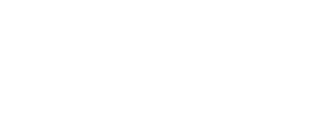
. . . . - 


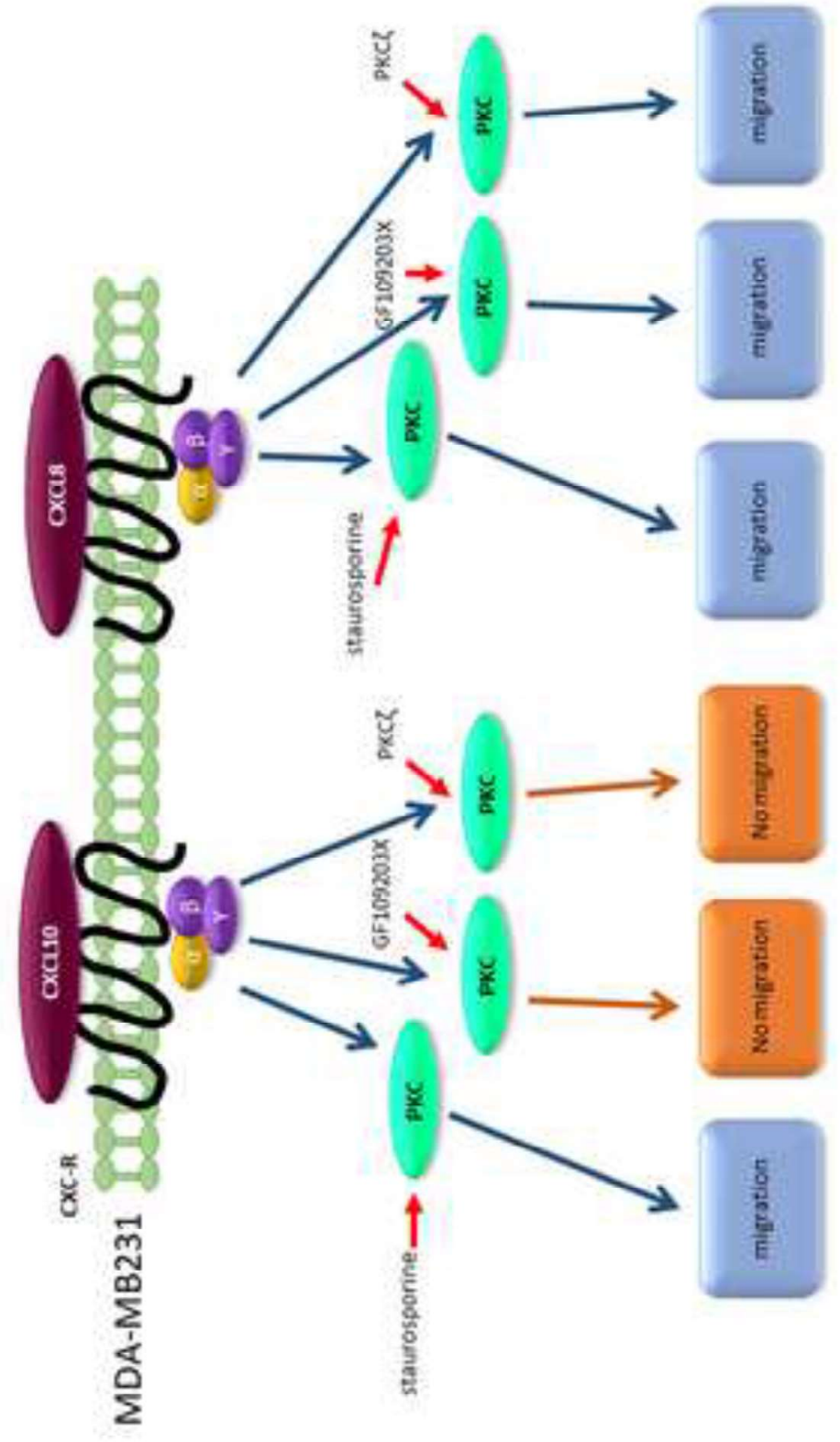




\section{Credit statement}

Enana Al-Assaf: Conceptualization, Investigation, Writing - Original Draft, Writing - Review \& Editing, Visualization

Anja Mueller: Conceptualization, Writing - Original Draft, Writing - Review \& Editing, Visualization Supervision 